\title{
EFFECT OF COOLING RATE FROM SOLUTION HEAT TREATMENT ON WASPALOY MICROSTRUCTURE AND PROPERTIES
}

\author{
J.R. Groh \\ Engineering Materials Technology Laboratories \\ GE Aircraft Engines \\ Evendale, OH
}

\begin{abstract}
Achievement of critical dimensions after wholesale removal of stock from large, ring rolled Waspaloy forgings and fabrications has been complicated by residual stresses induced via rapid quench from the solution heat treat cycle. Part movement during machining can be reduced significantly by substituting air cool for the oil quench commonly specified to achieve high mechanical strengths. However, excessive time in the sub- $\gamma^{\prime}$ solvus temperature range during slow cooling results in undesirable precipitate coarsening with an attendant degradation in strengths. Therefore, cooling rates must be achieved which strike a balance between manufacturing ease and property controlling microstructural features.

This report provides microstructural and mechanical property data for flash welded, shaped Waspaloy bar stock subjected to various cooling rates from a $1018^{\circ} \mathrm{C} / 4$ hour solution cycle followed by a stabilize and age heat treat. Average cooling rates evaluated in this investigation ranged from 5.5 to $145^{\circ} \mathrm{C} /$ minute through the $\gamma$ precipitation temperature range of 982 through $760^{\circ} \mathrm{C}$. Oil quench data from production hardware are also provided for reference. A significant improvement in 538 and $760^{\circ} \mathrm{C}$ yield strengths, $760^{\circ} \mathrm{C}$ tensile strengths, and $704^{\circ} \mathrm{C}$ creep resistance were significantly improved by increasing cooling rates. Ductility simultaneously decreased at $760^{\circ} \mathrm{C}$ but did not exhibit dependence at $538^{\circ} \mathrm{C}$. Minimum cooling rates of approximately $40^{\circ} \mathrm{C} /$ minute were necessary to approach the properties and microstructural features typical of oil-quenhed Waspaloy.
\end{abstract}

\section{Introduction}

Waspaloy has been used successfully in turbine case applications which require a balance of fatigue and creep resistance with tensile capability. Additional considerations for this application include grain structure for weldability and residual stresses from fabrication and heat treat which may result in part movement during machining.

Primary $\gamma$ has been used to control Ni-base microstructures during forge and heat treat cycles which significantly affect mechanical properties (ref. 1). Balanced properties are achieved via temperature selection relative to the $\gamma$ solvus which is a strong function of hardener content. Excessive exposure to sub-solvus temperatures reduces the amount of hardener available for precipitation hardening. Super-solvus operations late in the process coarsens grain size which degrades tensile and fatigue strengths.

$$
\text { Superalloys } 1996
$$

Edited by R. D. Kissinger, D. J. Deye, D. L. Anton,

A. D. Cetel, M. V. Nathal, T. M. Pollock, and D. A. Woodford

The Minerals, Metals \& Materials Society, 1996
Destructive mechanical tests of a large casing which had been solution heat treated in vacuum followed by argon cooling for manufacturing ease revealed unacceptable creep and tensile properties. Slow cooling from the sub-solvus solution temperature at $5.5^{\circ} \mathrm{C} /$ minute, nominal, through the sub- $\gamma$ solvus range had generated a coarsened $\gamma$ precipitate structure. Subsequent stabilization and aging cycles further overaged this structure. Resulting properties showed a $10-100 \mathrm{X}$ reduction in time to $0.2 \%$ creep and 50-170 MPa reduction in tensile strengths. Straincontrol low cycle fatigue behavior was not affected (ref. 2).

Simply switching to rapid oil quench from the solution temperature to improve properties was not considered an acceptable option as unknown residual stress patterns result. This project was performed to determine the minimum cooling rate which is necessary to achieve a microstructure which yields an acceptable balance of mechanical properties. The resulting property trends, coupled with heat transfer models of the quench from solution, have provided data used to identify a cooling method for production hardware to obtain mechanical properties similar to oil quenched forgings with minimal residual stress.

\section{Materials and Experimental Procedure}

Material and Heat Treatment

Material for this study was shaped bar stock processed by Teledyne Alvac from VIM+VAR ingot (heat BR12, $\gamma$ solvus $1043^{\circ} \mathrm{C}$ ) to the requirements of AMS5706. Heat chemistry follows in table I. Grain structure was equiax with an average grain size of ASTM 6-7.

Cooling rate blanks measured $53 \mathrm{~mm}$ in length with a chromelalumel thermocouple centered in the roughly $25 \mathrm{~mm}$ square end and embedded $12 \mathrm{~mm}$ deep. Most solution heat treatments were performed in air at $1018^{\circ} \mathrm{C}$ for 4 hours. Various combinations of insulation batting and a steel retort were used to achieve cooling rates which varied from an average of 20 to $145^{\circ} \mathrm{C} /$ minute between 982 and $760^{\circ} \mathrm{C}$. An additional sample was prepared at $5.5^{\circ} \mathrm{C} /$ minute in a vacuum furnace to enable programming of this relatively slow cool to simulate the hardware discussed above. All material blanks were then subjected simultaneously to the standard stabilize $\left(843^{\circ} \mathrm{C} / 4\right.$ hours) and age $\left(760^{\circ} \mathrm{C} / 16\right.$ hours) heat treat cycles specified in AMS5707. 
TABLE I

Waspaloy Heat BR12

(Weight \%)

\begin{tabular}{|c|c|c|c|c|c|c|}
\hline $\mathrm{C}$ & $\mathrm{Mn}$ & $\mathrm{Si}$ & $\mathrm{E}$ & $\mathrm{S}$ & $\mathrm{Cr}$ & $\mathrm{Al}$ \\
\hline .058 & .04 & .06 & .005 & .0004 & 19.45 & 1.37 \\
\hline $\mathrm{Ni}$ & $\mathrm{Me}$ & $\mathrm{Ce}$ & $\mathrm{I}$ & $\mathrm{Al+Ti}$ & $\mathrm{Bi}$ & $\mathrm{Pb}$ \\
\hline $\mathrm{Bal}$ & 3.89 & 12.38 & 2.91 & 4.28 & $<.0001$ & $<.0001$ \\
\hline $\mathrm{Se}$ & $\mathrm{B}$ & $\mathrm{Cu}$ & $\mathrm{Fe}$ & $\mathrm{Zr}$ & $\mathrm{Nb}$ & $\mathrm{Ta}$ \\
\hline$<.00005$ & .006 & .02 & 1.02 & .06 & .06 & .02 \\
\hline
\end{tabular}

\section{Metallography}

A $12 \mathrm{~mm}$ slice was removed from one end (transverse to rolling) of each fully heat treated blank for standard mechanical polishing techniques through $0.3 \mu$ diamond. Subsequent electropolishing and electroetching were performed in the same $10 \%$ perchloric $\left(\mathrm{HClO}_{4}\right)+$ methanol solution with the former at 30 volts for 15 seconds and the latter at $6 \mathrm{~V}$ for 5 seconds. Specimen crosssections were nominally $12 \mathrm{~mm}$ square. Electropreparation time was maintained constant regardless of microstructure to enable unbiased microstructural comparisons.

High resolution scanning electron microscopy (field emission electron gun) was used to document $\gamma$ and carbide morphologies. Depending on precipitate size, the area percent $\gamma$ was measured at either $25 \mathrm{~K}$ or $50 \mathrm{~K}$ magnification. A manual point count was performed in accondance with ASTM E562 (ref. 4) to quantify observations. SEM evaluation was also performed on test material from an oil quenched AMS5707 component with an average ASTM 5.-5.5 grain size from a different heat, included as reference

\section{Mechanical Testing}

All spocimens were machined parallel to the rolling direction by Accurate Metallurgical Services. Gage sections measured $4 \mathrm{~mm}$ in diameter by $19 \mathrm{~mm}$ with an overall specimen length of $50 \mathrm{~mm}$ (GE drawing \#4013195-001). The test gage of each specimen was immediately adjacent to the embedded thermocouple lead used to verify cooling rate.

Mechanical tests consisted of 538 and $760^{\circ} \mathrm{C}$ tensile per ASTM E21 and $704^{\circ} \mathrm{C} / 427 \mathrm{MPa}$ creep per ASTM E139 with the stress axis parallel to the rolling direction. Average tensile and time to creep data from production oil quenched AMS 5707 components with an average ASTM 5.-5.5 grain size from various heats have been included for reference. Oil quench was not part of this study due to the limited amount of material.

\section{Experimental Results}

Metallography

Optical micrograph of grain structure is provided in Figure 1. High resolution SEM photomicrographs at $50,000 \mathrm{X}$ of the 5.5 , $25,40,63,145^{\circ} \mathrm{C} /$ minute and oil quenched samples are provided in Figure 2. Age $\gamma$ size decreased from $0.16 \mu \mathrm{m}$ to the $0.06-0.07$ $\mu \mathrm{m}$ range by increasing from 5.5 to $40^{\circ} \mathrm{C} /$ minute. Faster quench did not achieve the $0.04 \mu \mathrm{m}$ recorded for oil quenched material. Area percent of age $\gamma$ was normalized relative to the point count data generated for the oil quench from solution+stabilize and aged specimen. The measured area \% data continued to increase through $63^{\circ} \mathrm{C} /$ minute before leveling. Primary $\gamma$ size was reduced by increasing quench rate but also leveled at $40^{\circ} \mathrm{C}$ /minute. Primary $\gamma$ fraction and grain sizes were not significantly affected by cooling rate. The balance of microstructural features are provided in Table $\mathrm{L}$.

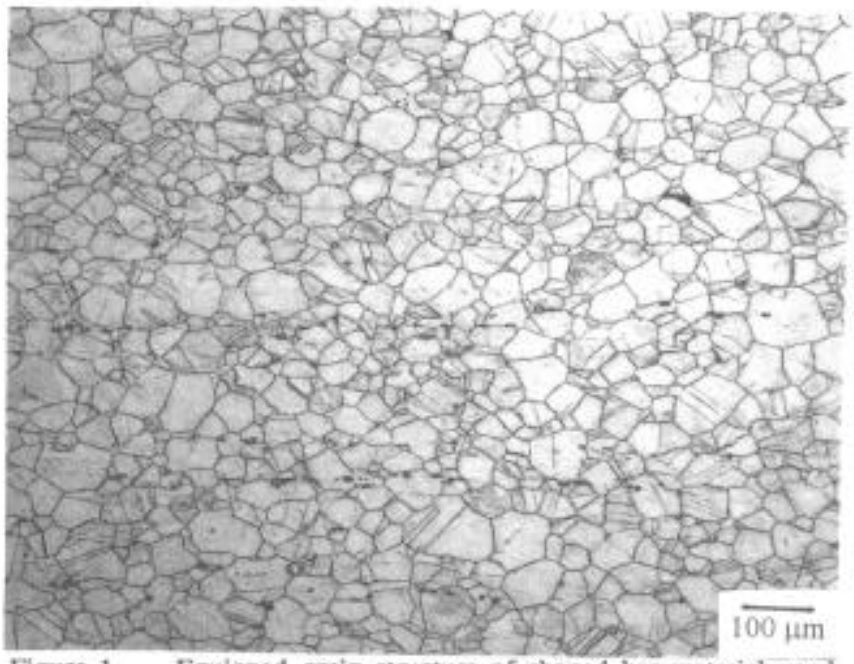

Figure 1 Equiaxed grain structure of shaped bar material used in this investigation. ASTM 6-7 average grain size,

TABLE II

AMS5707 Waspaloy

Microstructural Features

\begin{tabular}{|c|c|c|c|}
\hline Cooling Rate & $\begin{array}{c}\text { Age } \gamma^{\prime} \\
\text { size }(\mu \mathrm{m})\end{array}$ & $\begin{array}{c}\text { Normalized } \\
\text { \% Age } \gamma\end{array}$ & $\begin{array}{c}\text { Primary } \gamma \\
\text { size }(\mu \mathbf{m})\end{array}$ \\
\hline $\mathbf{5 . 5 ^ { \circ }} \mathbf{C} / \mathbf{m i n}$ & 0.16 & 0.35 & 0.40 \\
\hline $\mathbf{2 5}^{\circ} \mathbf{C} / \mathbf{m i n}$ & 0.12 & 0.35 & 0.35 \\
\hline $\mathbf{4 0}^{\circ} \mathbf{C} / \mathbf{m i n}$ & 0.07 & 0.52 & 0.30 \\
\hline $\mathbf{6 3}^{\circ} \mathbf{C} / \mathbf{m i n}$ & 0.06 & 0.82 & 0.30 \\
\hline $\mathbf{1 4 5}^{\circ} \mathbf{C} / \mathbf{m i n}$ & 0.06 & 0.82 & 0.30 \\
\hline $\begin{array}{c}\text { Oil } \\
\text { (Reference) }\end{array}$ & 0.04 & 1. & 0.30 \\
\hline
\end{tabular}

Mechanical Propertics

The results of tensile and a summary of creep data are presented in tables III and IV, respectively. Figure 3, depicts the ultimate and $0.2 \%$ yield strength data as a function of cooling rate. Figure 4 shows the influence of cooling rate on tensile ductilities. Plots of creep strain time pairs for each cooling rate evaluated are provided in Figure 5. With the exception of $538^{\circ} \mathrm{C}$ UTS and ductilities, regression models for each property versus cooling rate are provided in Table V.

TABLE III

AMS5707 Waspaloy

Tensile Data

\begin{tabular}{|c|c|c|c|c|c|}
\hline $\begin{array}{c}\text { Cooling } \\
\text { Rate } \\
\left({ }^{\circ} \mathbf{C} / \mathbf{m i n}\right)\end{array}$ & $\begin{array}{c}\text { Test } \\
\text { Temp } \\
\left({ }^{\circ} \mathbf{C}\right)\end{array}$ & $\begin{array}{c}\text { UTS } \\
(\mathrm{MPa})\end{array}$ & $\begin{array}{c}\mathbf{0 . 2 \%} \\
\mathbf{Y S} \\
(\mathbf{M P a})\end{array}$ & $\begin{array}{c}\text { Elongation } \\
(\%)\end{array}$ & $\begin{array}{c}\text { Reduction } \\
\text { of Area } \\
(\%)\end{array}$ \\
\hline $\mathbf{5 . 5}$ & 538 & 1156 & 714 & 24.0 & 32 \\
\hline $\mathbf{2 5}$ & 538 & 1193 & 845 & 21.9 & 30.3 \\
\hline $\mathbf{4 0}$ & 538 & 1207 & 794 & 21.9 & 30.5 \\
\hline $\mathbf{6 3}$ & 538 & 1163 & 840 & 23.4 & 35.8 \\
\hline $\mathbf{1 4 5}$ & 538 & 1175 & 834 & 23.4 & 31.7 \\
\hline $\begin{array}{c}\text { Oil } \\
(\text { ref.) }\end{array}$ & 538 & 1189 & 807 & 20.0 & 28.4 \\
\hline $\mathbf{5 . 5}$ & 760 & 884 & 585 & 36.0 & 61.1 \\
\hline $\mathbf{2 5}$ & 760 & 984 & 728 & 26.6 & 50.9 \\
\hline $\mathbf{4 0}$ & 760 & 982 & 651 & 21.9 & 57.4 \\
\hline $\mathbf{6 3}$ & 760 & 1065 & 820 & 12.5 & 41.4 \\
\hline $\mathbf{1 4 5}$ & 760 & 1172 & 920 & 15.6 & 28.7 \\
\hline $\begin{array}{c}\text { Oil } \\
\text { (ref.) }\end{array}$ & 760 & 931 & 759 & 17 & 28.2 \\
\hline
\end{tabular}



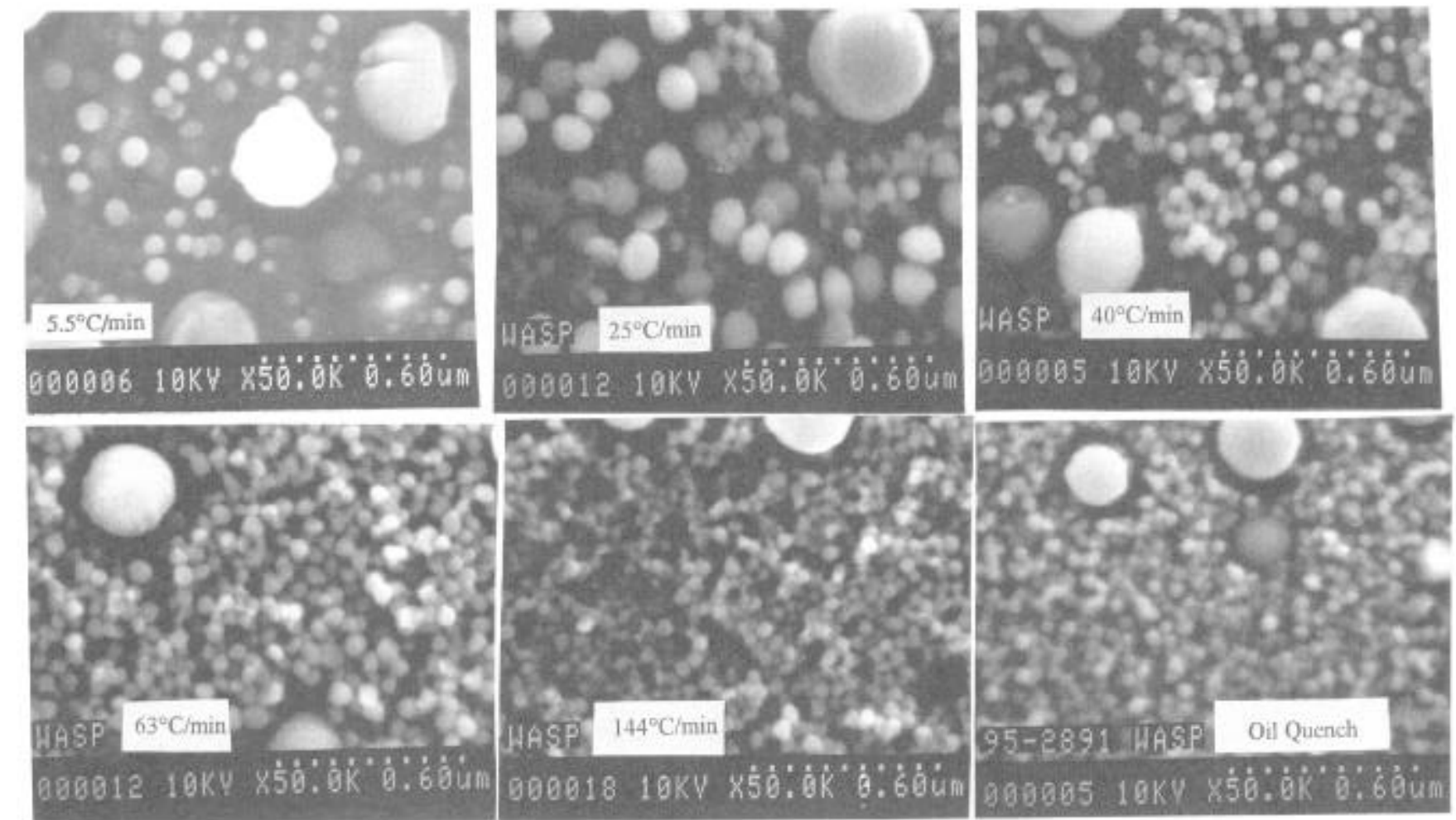

Figure 2

High resolution SEM micrographs of AMS5707 Waspaloy cooled from solution at indicated cooling rates followed by stabilize and age. Micrograph representing a solution+oil quench, stabilize and age heat treated component is also provided for reference.
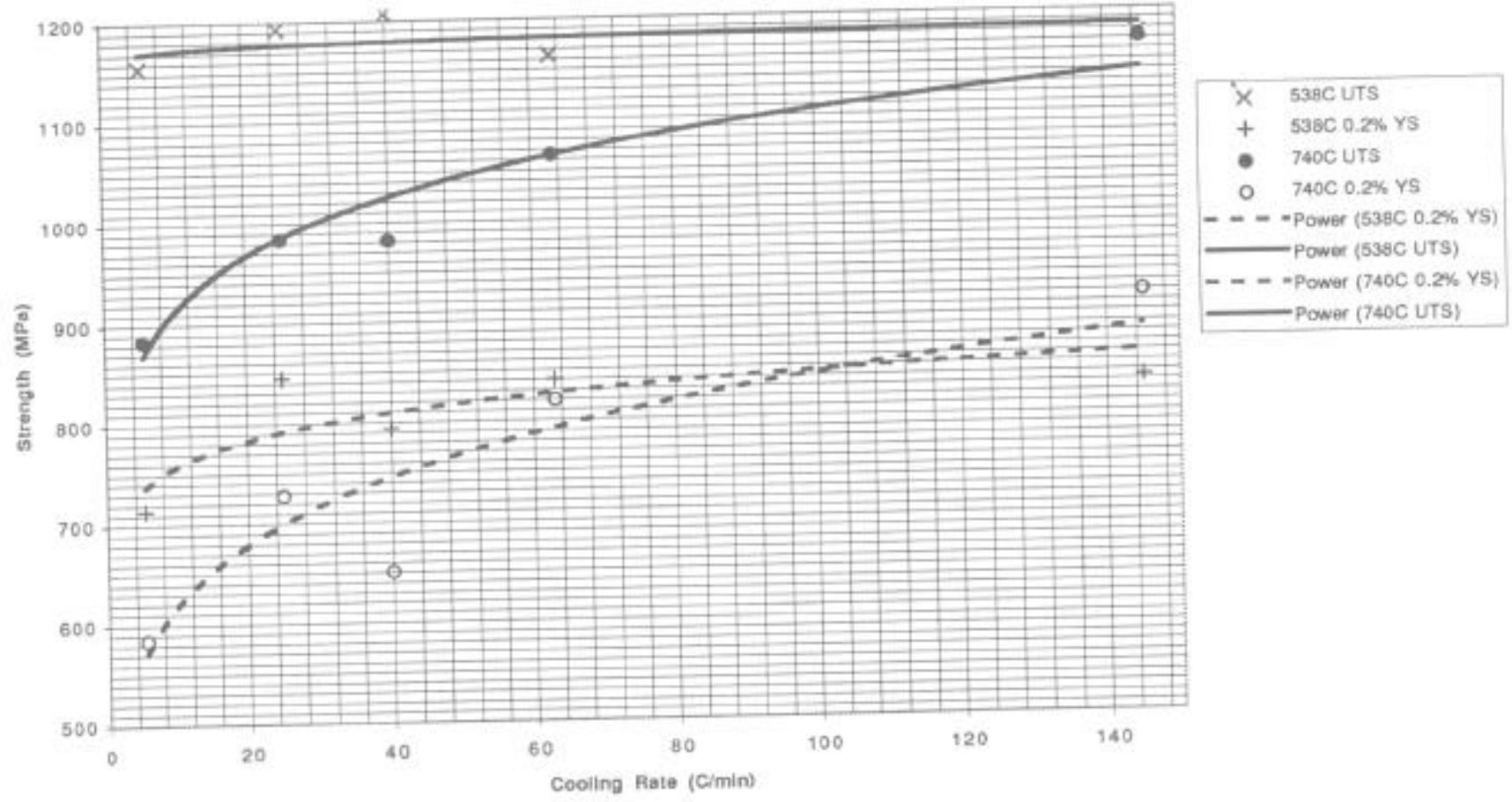

Figure 3

Plot of cooling rate vs. tensile strength data. Strengths continue to improve with increasing cooling mate at $760^{\circ} \mathrm{C}$. At $538^{\circ} \mathrm{C}$ only the yield strength shows an initial improvement, ultimate was not affected at this temperature. 


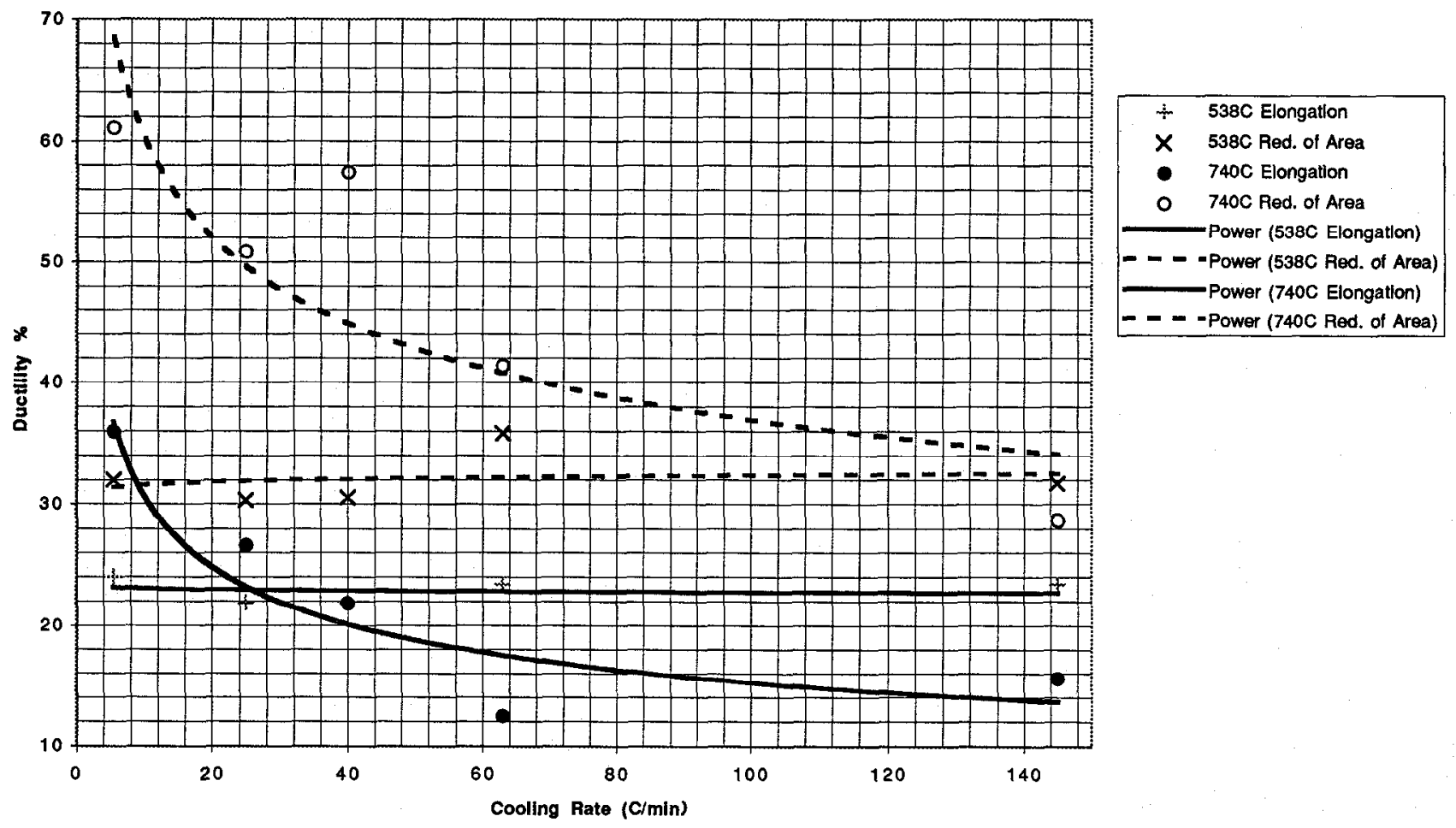

Figure 4 Plot of cooling rate vs. tensile ductility data. Ductilities continue to improve with increasing cooling rate at $760^{\circ} \mathrm{C}$. Neither measure showed a relationship to cooling rate at $538^{\circ} \mathrm{C}$.
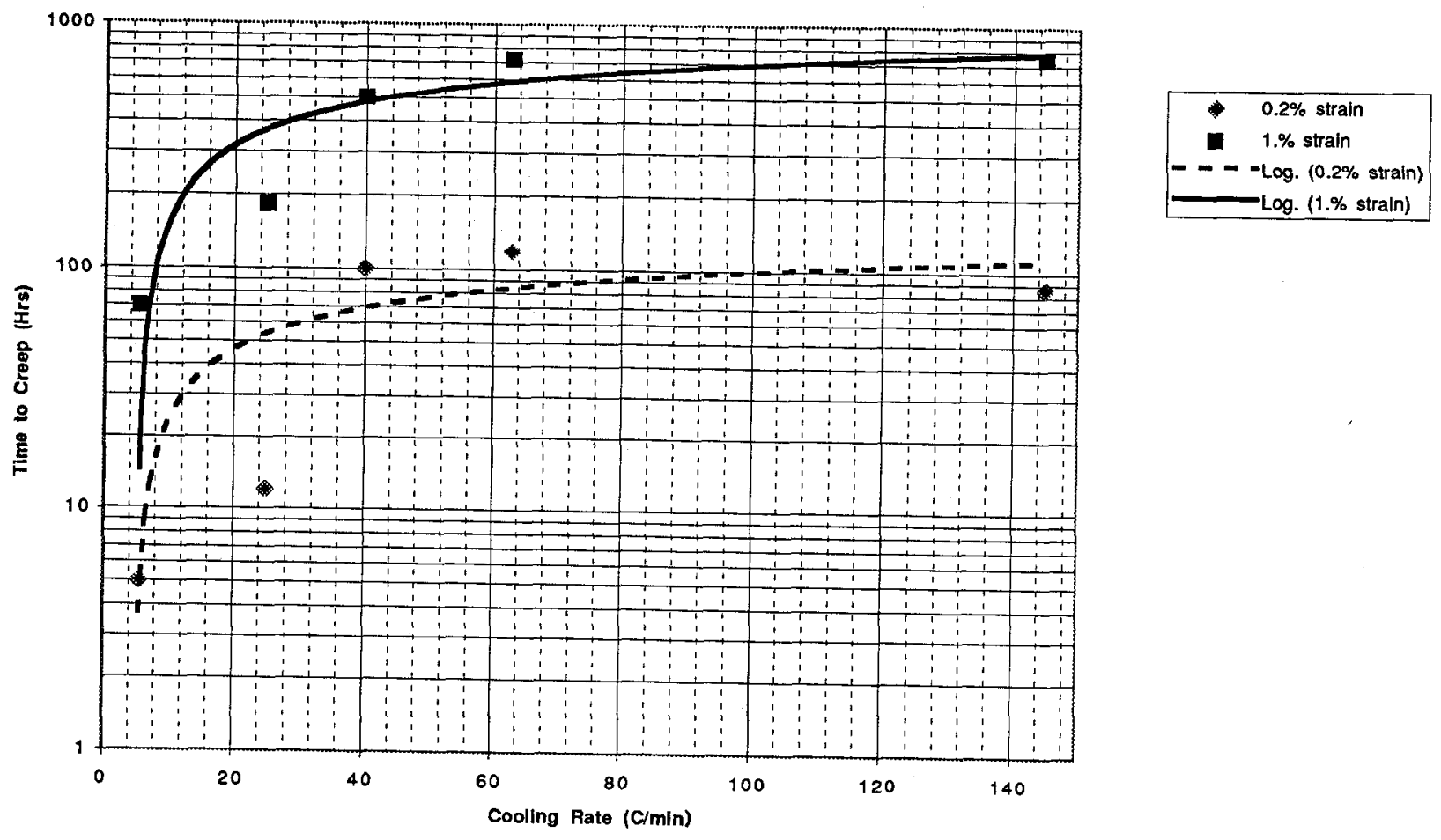

Figure 5

Plot of cooling rate vs. time to 0.2 and $1.0 \%$ creep for $704^{\circ} \mathrm{C} / 427 \mathrm{MPa}$. Creep resistance improved with cooling rate through $-40^{\circ} \mathrm{C} /$ minute then tapered to a level approaching oil quenched Waspaloy of this grain size. 
TABLE IV

AMS5707 Waspaloy

$7^{\circ} \mathrm{C} / 427 \mathrm{MPa}$ Creep Data

\begin{tabular}{|c|c|c|c|c|}
\hline $\begin{array}{c}\text { Cooling } \\
\text { Rate } \\
\left({ }^{\circ} \mathrm{C} / \mathrm{min}\right)\end{array}$ & $\begin{array}{c}\text { Time to } \\
\mathbf{0 . 1 \%} \varepsilon \\
(\text { Hours })\end{array}$ & $\begin{array}{c}\text { Time to } \\
\mathbf{0 . 2 \% \varepsilon} \\
(\text { Hours })\end{array}$ & $\begin{array}{c}\text { Time to } \\
\mathbf{0 . 5 \% \varepsilon} \\
(\text { Hours) }\end{array}$ & $\begin{array}{c}\text { Time to } \\
\text { (Hours) }\end{array}$ \\
\hline $\mathbf{5 . 5}$ & 0.2 & 0.5 & 1.6 & 4.6 \\
\hline $\mathbf{2 5}$ & & 12 & 78 & 183 \\
\hline $\mathbf{4 0}$ & 43 & 100 & 269 & 500 \\
\hline $\mathbf{6 3}$ & 28 & 119 & 420 & 724 \\
\hline $\mathbf{1 4 5}$ & 4 & 86 & $\overline{388}$ & 748 \\
\hline $\begin{array}{c}\text { Oil } \\
\text { (ref.) }\end{array}$ & 54 & 450 & $\begin{array}{c}\text { not } \\
\text { available }\end{array}$ & $\begin{array}{c}\text { not } \\
\text { available }\end{array}$ \\
\hline
\end{tabular}

Table V

Property vs. Cooling Rate Regressions

\begin{tabular}{|c|c|c|}
\hline \multicolumn{2}{|c|}{$538^{\circ} \mathrm{C} 0.2 \%$ YS $=680.09 *(\text { cooling rate })^{0.0471}$} & \\
\hline \multicolumn{2}{|c|}{$538^{\circ} \mathrm{C}$ UTS, $\% \mathrm{El}$, and $\%$ RA not $\mathrm{f}$ (cooling rate) } & \\
\hline \multicolumn{2}{|c|}{$740^{\circ} \mathrm{C} 0.2 \%$ YS $=454.9^{*}(\text { cooling rate })^{0.1339}$} & \\
\hline $740^{\circ} \mathrm{C}$ & & \\
\hline $740^{\circ} \mathrm{C}$ & & \\
\hline $740^{\circ} \mathrm{C}$ & )$^{-0.2131}$ & $=0.72$ \\
\hline $\mathrm{ti}$ & $r s)_{0.24}=$ & $\begin{array}{l}R^{2}=0.59 \\
R^{2}=0.85\end{array}$ \\
\hline
\end{tabular}

\section{Discussion}

Laboratory cooling rates did exhibit a pronounced effect on microstructure and resulting mechanical properties. In general, a greater percentage of age $\gamma$ was realized with increasing cooling rates which improved properties. Reduction in age $\gamma$ size coincides with a change in morphology from slightly cuboidal to spheroidal. A slight decrease in primary $\gamma$ size was also measured relative to the two slowest rates as the time of exposure to subsolvus temperatures was reduced.

Age $\gamma$ percents were normalized to the oil quench specimen as the measured volume \% data was higher than theoretical due to the specimen preparation techniques used in this study. Constant electro polish and etch of all specimens provided different depths of attack which is a function of structure. A more accurate metallographic determination could be obtained via replication techniques although the depth of etch variable may still be an issue. Determination of the actual volume fraction requires phase extraction.

Tensile strengths and ductilities at $760^{\circ} \mathrm{C}$ were influenced by cooling rate to a greater degree than at $538^{\circ} \mathrm{C}$. The insensitivity of UTS, \%El and \%RA at $538^{\circ} \mathrm{C}$ was somewhat surprising as reference 5 documents cooling rate dependent behavior for Rene'88DT similar to that observed in this study at both 400 and $649^{\circ} \mathrm{C}$. $\mathrm{R}^{\prime} 88 \mathrm{DT}$ is a relatively high hardener Ni-base powder alloy which differs in that solution heat treatment is accomplished above the $\gamma^{\prime}$-solvus temperature.
A trend of improved creep resistance was observed for both $0.2 \%$ and $1.0 \% \varepsilon$ at $704^{\circ} \mathrm{C} / 427 \mathrm{MPa}$ over the 1000 hours tested. The trend in $0.1 \%$ creep lives versus cooling rate did not track well versus cooling rate (table IV). The primary creep rate of the $145^{\circ} \mathrm{C} /$ minute specimen was relatively fast which caused the time to $0.1 \% \varepsilon$ to be less than that recorded for the 40 and $63^{\circ} \mathrm{C} / \mathrm{min}$. samples. Higher creep strains showed a much better progression of time versus cooling rate. Cross-over occurred at roughly $0.25 \%$ strain with a relatively strong trend of increasing strain versus cooling rate for a given time above this level.

The recent investigation of R'88DT (reference 5) supports the results of this study. Similar improvements in tensile strengths were most significant between 7 and $40^{\circ} \mathrm{C} /$ minute. Further increases in cooling rate resulted in relatively modest tensile strength improvements. Marked further improvements in $704^{\circ} \mathrm{C}$ creep resistance were observed when oil quenched solution. Similar benefits would be expected for Waspaloy based on the aging $\gamma$ data provided in this report.

Waspaloy microstructural features and testing indicated that a significant improvement in properties relative to the argon cooling process could be realized at cooling rates as low as $40^{\circ} \mathrm{C} / \mathrm{min}$. Average rates of $63^{\circ} \mathrm{C} / \mathrm{min}$ or faster are preferred if the resulting residual strains are tolerable during fabrication.

Since project complction, scveral casings were rapid fan air cooled from the solution cycle which achieved a satisfactory cooling rate of $44^{\circ} \mathrm{C}$ /minute. The benefit to mechanical properties was substantiated via mechanical testing prolong material at the conditions evaluated in this report (ref. 3). SEM metallography of very small sections removed from stock added areas of subsequent production hardware has been used as a non-destructive tests to confirm adequate cooling. Problems due to distortion during machining of this component were nol encountered with this procedure. 


\section{Conclusions}

1. Morphology of $\gamma$ precipitates was a strong function of cooling rate from the solution temperature. Structures approaching that achieved by oil quench were achieved at cooling rates as low as $40^{\circ} \mathrm{C} /$ minute.

2. Waspaloy $760^{\circ} \mathrm{C}$ tensile and $704^{\circ} \mathrm{C}$ creep properties were shown to be highly dependent on cooling rate from the solution temperature. At $538^{\circ} \mathrm{C}$, tensile yield strength showed improvement with increasing cooling rate; however, the UTS and ductilities were not affected.

3. Models of tensile properties and creep resistance as a function of cooling rate were generated.

4. Minimum cooling rates of $40^{\circ} \mathrm{C} /$ minute are needed to approach the tensile and creep design curves generated from relatively small, oil quenched forgings.

5. The production rapid fan air cool cycle from the solution heat treatment temperature yielded $\gamma$ morphologies sufficient to provide mechanical behaviors comparable to those of the design curves generated from parts oil quenched from solution.

6. SEM evaluation of precipitate morphology is an effective method to confirm that the appropriate heat treatment and anticipated properties are achieved.

\section{References}

1. P.R. Bhowal, E.F. Wright, and E.L. Raymond, "Effects of Cooling Rate and $\gamma$ Morphology on Creep and Stress-rupture Properties of a Powder Metallurgy Superalloy", Metallurgical Transactions A, 21A (1990), 1709-1717

2. W.P. Rehrer, D.R. Muzyka, and G.B. Heydt, "Solution Treatment and Al+Ti Effects on the Structure and Tensile Properties of Waspaloy", Journal of Metals (1970), 32-39.

3. Jon Groh, internal GE report dated 4/5/95.

4. ASTM E562 "Standard Practice for Determining Volume Fraction by Systematic Manual Point Count" dated 1983.

5. E.S. Huron, internal GE report dated 2/1/95.

6. AMS5706, "Alloy Bars, Forgings, and Rings, Corrosion and Heat Resistant ; 1825 to 1900 F solution Heat Treated" 